\title{
EFFECTS OF MATERNAL NUTRITION STATUS, MATERNAL EDUCATION, MATERNAL STRESS, AND FAMILY INCOME ON BIRTHWEIGHT AND BODY LENGTH AT BIRTH IN KLATEN, CENTRAL JAVA
}

\author{
Rika Nurmayanti1 ${ }^{1)}$, Harsono Salimo ${ }^{2)}$, Yulia Lanti Retno Dewi3) \\ ${ }^{1)}$ Masters Program in Public Health, Sebelas Maret University \\ 2)Department Pediatrics, Dr. Moewardi Hospital, Surakarta \\ 3)Department of Nutrition, Faculty of Medicine, Sebelas Maret University
}

\begin{abstract}
Background: Birthweight and body length at birth are predictors of morbidity and mortality in children under five years old and adult age. Low birthweight increases the risk of morbidity and mortality in children under five. This study aimed to examine the effects of maternal nutrition status, maternal education, maternal stress, and family income, on birthweight and body length at birth in Klaten, Central Java.

Subjects and Method: This was an observational analytic study with case control design. The study was conducted at Manisrenggo and Bayat community health centers, Klaten District, Central Java, in April 2017. A total sample of 120 children aged o to 6 months and their mothers were selected for this study using fixed disease sampling. The dependent variables were birthweight and body length and birth. The independent variables were maternal nutrition status, maternal education, maternal stress, and family income. The data were collected by a set of questionnaire. Maternal nutrition status at pregnancy was measured by mid-upper arm circumference (MUAC). Data on birthweight and body length at birth were taken from mother and child health monitoring book. The data was analyzed using path analysis.

Results: Birthweight was directly and positively affected by maternal MUAC at pregnancy $(b=0.50 ; S E=0.13 ; p<0.001)$, family income $(b=0.11 ; S E=$ $0.04 ; \mathrm{p}=0.004)$, and maternal education $(\mathrm{b}=2.14 ; \mathrm{SE}=0.88 ; \mathrm{p}=0.016)$. Birthweight was directly and negatively affected by maternal stress $(b=-1.81$; $\mathrm{SE}=0.81 ; \mathrm{p}=0.025)$. Body length at birth was directly and positively affected by maternal MUAC at pregnancy $(b=0.16 ; \mathrm{SE}=0.64 ; \mathrm{p}=0.011)$ and family income $(b=0.05 ; \mathrm{SE}=0.18 ; \mathrm{p}=0.005)$. Maternal MUAC at pregnancy was affected by maternal education $(b=1.41 ; \mathrm{SE}=0.58 ; \mathrm{p}=0.014)$. Likewise, family income was affected by maternal education $(b=5.28 ; \mathrm{SE}=2.11 ; \mathrm{p}=$ 0.012).

Conclussion: Maternal MUAC at pregnancy, family income, and maternal education positively and directly affect birthweight. Maternal stress directly and negatively affects birthweight. Body length at birth is directly and positively affected by maternal MUAC at pregnancy and family income.
\end{abstract}

Keywords: birthweight, body length at birth, MUAC, maternal stress

Correspondence: Rika Nurmayanti. Masters Program in Public Health, Sebelas Maret University, Jl. Ir. Sutami 36 A, Surakarta 57126, Central Java. Email: yicha.adjach@gmail.com. Mobile: +6281270333572. 